\title{
Development strategy of home industry Golla Kambu in Lagi- Agi Village, Campalagian Subdistrict, Polewali Mandar Regency
}

\author{
Mardiana ${ }^{1}$, Rahma Khaerati ${ }^{*}$, Anwar Sulili3 ${ }^{3}$, and Muhammad Arhim ${ }^{4}$ \\ 1,2,4Agribusiness Department, Universitas Sulawesi Barat, Indonesia \\ ${ }^{3}$ Socio-economic of Agriculture Department, Universitas Hasanuddin, Indonesia \\ *Corresponding author's e-mail: rahmakhaerati559@gmail.com \\ Received November 30th, 2019; revised January 3rd, 2020; accepted January 10th, 2020
}

\begin{abstract}
Home industry in Polewali Mandar Regency in 2014 reached 6,035 industries. The number of micro and small businesses increased 1.34 percent. The workforce involved in micro and small industries reached 13,470 people. Polewali Mandar main area which incidentally has a Mandar tribe has some special culinary. One of them is Golla Kambu or what is commonly called Wajik Lokal Mandar. These local Mandar food entrepreneurs adjust the market because it has become a typical local snack. In fact, now Golla Kambu has been eyeing foreign tourists when they travel in West Sulawesi. Along the road in Lagi-Agi Village, Campalagian Subdistrict precisely Polewali Mandar, many of the Mandar local food are often found. Along the way we will find many stalls that provide this food with different prices and flavors. One of the other advantages of this food is that it is durable, even though it does not use preservatives, Golla Kambu can last for months using only a wrapper of dried banana leaves. To make Golla Kambu is actually very simple, practical and the material is easy to obtain. The basic ingredients are only three, namely selected glutinous rice, palm sugar and young grated coconut. Three main ingredients are mixed into one, put in a suitable bowl or place and then cooked for several hours to form a good mixture. The end result is then wrapped in dried banana leaves in a small size. Besides its simple taste, the price is quite affordable for visitors. The famous Golla Kambu in Mandar comes from the area of Lagi-Agi Village, Campalagian Subdistrict, Polewali Mandar Regency.
\end{abstract}

Keywords:

Golla kambu, Strategy, Local mandar food, Small industry

\section{Introduction}

Small business as one of source in the economic activities of the community is an interesting phenomenon that needs to be followed continuously and constructed so that it can grow and play a bigger role in the Indonesian economy. The number of entrepreneurs is so much, they are not growing but decreasing and experiencing losses and bankruptcy. Some persist in its business, some of which are thriving but not infrequently, which only runs in place. Small industries in Indonesia have various types of businesses. The existence of small industries in Indonesia has had an important role in the national economy, especially in the aspect of increasing employment opportunities, equitable income generation, rural economic development and increase in non-oil exports [1].

Golla Kambu product is a product whose manufacturing process is still very simple and does not use preservatives in its mixture, because of that, so that Golla Kambu can be categorized as a healthy product so that it can become a major force in efforts to increase marketing. Healthy and safe snacks are snacks that are free from physical hazards, chemical contamination, and biological hazards [2]. 
The production process of the Golla Kambu still uses a furnace, where the main fuel (wood) used in the cooking process is still very easy to obtain in the surrounding area without incurring costs, although some use the cost, but the price is relatively cheaper compared to the price of fuel oil. The high availability of raw materials such as coconut which is still very easy to obtain causes the business to have greater strength to produce Golla Kambu This is because the total area of smallholder plantations in the Polewali Mandar Regency in 2010 as a whole was 83,428.77 hectares, from that area of 56,633, $48 \mathrm{Ha}$ is the area of productive plantations. The largest production of plantation crops in Polewali Mandar Regency in 2010 was cocoa and coconut, with production of 27,938.30 tons and 18,808.27 tons, respectively [3].

Indonesia has the lowest average minimum monthly wage of 83.82 USD or around Rp 1,099 million and the highest is 205.74 USD or around Rp 2,699 million (National Wages and Productivity Commission). Based on the determination of the provincial minimum wage in 2014 the province of West Sulawesi with the stipulation of a minimum wage of $\operatorname{Rp~1,400,000~per~month~[4].~Meanwhile,~the~average~wage~of~}$ labor in the Golla Kambu business is Rp 361,000 per month. In this Golla Kambu business, capital is said to be limited because all entrepreneurs use their own capital, which the entrepreneurs are unable to increase capital to develop marketing. This condition causes the weakness of the Golla Kambu business to be able to develop until the weight of the Golla Kambu business weakness in this study is high.

The marketing system that has not been focused and the absence of the main target of the business product causes the marketing costs cannot be estimated yet. This causes each business to not yet have a fixed marketing area and cannot become the main supplier of a continuous Golla Kambu retailer business. Good marketing is to expand the market in the surrounding area but also reach potential markets. Market opportunity is an area of buyer needs where companies can operate profitably [5].

Promotion in a business is very important because promotion is an attempt to notify or offer a product or service with the aim of attracting potential customers to buy or consume it. However, in the Golla Kambu business, promotional activities are still very minimal because the promotions carried out by entrepreneurs are only verbal promotions, so this can be a weakness in the business of marketing their products. Promotion (promotion) is an element that is used to inform and persuade the market about a new product or service to a company through advertising, personal selling, sales promotion, or publication.

Golla Kambu product is one of the typical Mandar snacks that only has one shape, which is rectangular and has 4 types of flavors (peanuts, durian, sesame, original), so that the small variety of shapes and flavors is a weakness in an effort to increase marketing. Diversification is an effort to diversify the types of businesses. Diversification is a business that is often pursued by a company. Diversification is a strategy to develop new products for new markets [6]. The situation that supports the implementation of this strategy is that if there are no more growth opportunities for the current product or market, the market environment served is very unstable, and has an impact on sales or profit fluctuations, and the company intends to optimize its core competencies. From some of the opinions above, product diversification is an attempt by the company to diversify products or services by 
creating new products or services to suit the tastes and needs of consumers so as to increase sales [6]. Based on this background and problems, this study aims to: 1). Knowing the condition of human resources, technology, capital and marketing in the Golla Kambu business in Lagi-Agi Village, Campalagian Subdistrict, 2) Knowing the strategy for developing the Golla Kambu business in the Lagi-Agi Village, Campalagian Subdistrict.

\section{Method}

Table 1. SWOT factor analysis

\begin{tabular}{|c|c|c|c|c|}
\hline \multirow[b]{2}{*}{ 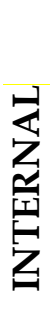 } & \multicolumn{2}{|l|}{ STRENGHT } & \multicolumn{2}{|c|}{ WEAKNESS } \\
\hline & $\begin{array}{l}\text { 1. Product without preserv } \\
\text { 2. Easy availability of raw } \\
\text { 3. Production equipment ca } \\
\text { simple equipment } \\
\text { 4. The wage rate of labor in } \\
\text { cheap. }\end{array}$ & $\begin{array}{l}\text { tives. } \\
\text { aterials. } \\
\text { use } \\
\text { ludes }\end{array}$ & $\begin{array}{l}\text { 1. At least va } \\
\text { taste. } \\
\text { 2. Promotion } \\
\text { 3. Limited-or } \\
\text { 4. Don't have } \\
\text { yet. }\end{array}$ & $\begin{array}{l}\text { lations of shape and } \\
\text { netivities. } \\
\text { ned capital. } \\
\text { fixed marketing area }\end{array}$ \\
\hline & OPPORTUNITY & ST & ГEGY S-O & STRATEGY W-O \\
\hline & $\begin{array}{l}\text { 1. Golla Kambu is one of } \\
\text { the typical Mandar } \\
\text { foods } \\
\text { 2. Population increase } \\
\text { 3. The level of labor } \\
\text { availability in the } \\
\text { surrounding areas }\end{array}$ & $\begin{array}{l}\text { 1. Utiliz } \\
\text { work } \\
\text { surro } \\
\text { incre } \\
\text { 2. More } \\
\text { agair } \\
\text { Villa } \\
\text { cente } \\
\text { Kam }\end{array}$ & $\begin{array}{l}\text { n of } \\
\text { e from } \\
\text { ling areas to } \\
\text { production } \\
\text { coducing } \\
\text { t Lagi-Agi } \\
\text { a typical food } \\
\text { cluding Golla }\end{array}$ & $\begin{array}{l}\text { Optimization of } \\
\text { business } \\
\text { management by } \\
\text { increasing capital so } \\
\text { that the goods are } \\
\text { produced more } \\
\text { maximal. }\end{array}$ \\
\hline & THREAT & & ГEGY S-T & STRATEGY W-T \\
\hline 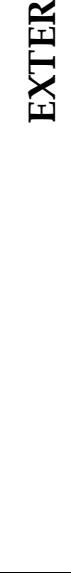 & $\begin{array}{l}\text { 1. It is not stable raw } \\
\text { material price. } \\
\text { 2. The living pattern of the } \\
\text { already modern society. } \\
\text { 3. Many modern food } \\
\text { retail producers. }\end{array}$ & $\begin{array}{l}\text { 1. Main } \\
\text { Tamp } \\
\text { be ab } \\
\text { with } \\
\text { 2. Incre } \\
\text { capit } \\
\text { price }\end{array}$ & $\begin{array}{l}\text { products of } \\
\text { reservatives to } \\
\text { compete } \\
\text { products. } \\
\text { he existing } \\
\text { meet the } \\
\text { aw materials. }\end{array}$ & $\begin{array}{l}\text { 1. Rely on } \\
\text { cooperation with } \\
\text { other merchants } \\
\text { outside the region } \\
\text { for a wider } \\
\text { distribution } \\
\text { process. } \\
\text { 2. To create } \\
\text { innovations in } \\
\text { product } \\
\text { packaging, to have } \\
\text { a high appeal. }\end{array}$ \\
\hline
\end{tabular}

This research was conducted in Lagi-agi Village, Campalagian Subdistrict, and data collection began in March to May 2017. To answer the objectives to be achieved in this study used the analysis method, namely SWOT Analysis. This analysis is used to find out what strategies will be used after seeing the strengths, weaknesses, opportunities and threats of the industry. SWOT analysis is a management tool for evaluating internal and external organization so that it can provide information about important issues for the organization/service. The SWOT analysis begins 
with the identification of positive aspects, namely strengths and negative aspects, namely weaknesses of the internal organization. While from external organizations, opportunities and threats are identified.

\section{Results and Discussion}

\subsection{Work Force Condition}

Based on the results of the research can be explained that the human resource conditions in Golla Kambu business in the Lagi-Agi Village, Campalagian Subdistrict as follows:

\subsubsection{Labor Use}

In using labor, employers must pay attention to the amount of labor needed. This relates to the amount of production costs and income of entrepreneurs. From Table 2 it is known that the amount of labor that is widely used in the Golla Kambu business in Lagi-agi Village, Campalagian Subdistrict is 10 workers, namely 3 businesses, for the use of 4-5 workers there are 2 businesses that use it. The number of workers between 2-3 people there is 1 business that uses it, and 4 businesses that use 1-2 workers.

Table 2. The use of Golla Kambu business workers in Lagi-Agi Village, Campalagian Subdistrict

\begin{tabular}{cccc}
\hline No. & Labor Use & Number & Percentage \\
\hline 1 & 7-10 people & 3 & $30 \%$ \\
2 & 4-5 people & 2 & $20 \%$ \\
3 & $2-3$ people & 1 & $10 \%$ \\
4 & 1-2 people & 4 & $40 \%$ \\
\hline & Total & 10 & $100 \%$ \\
\hline
\end{tabular}

Source: Primary data processed (2017)

\subsubsection{Work Force Education}

Table 3. The work force education of Golla Kambu business in Lagi-Agi Village, Campalagian Subdistrict

\begin{tabular}{cccc}
\hline No. & Work Force Education & Number & Percentage \\
\hline 1 & Bachelor & 0 & $0 \%$ \\
2 & Senior High School & 6 & $18,75 \%$ \\
3 & Junior High School & 12 & $37,5 \%$ \\
4 & Elementary School & 14 & $43,75 \%$ \\
\hline \multicolumn{2}{r}{ Total } & 32 & $100 \%$ \\
\hline
\end{tabular}

Source: Primary data processed (2017)

In 2017 the number of workers in Golla Kambu business in the Lagi-Agi Village, Campalagian Subdistrict was 32 people, with a level of education 6 people High School, junior high School 12 people and the level of education as many as 14 people. 


\subsubsection{Working Hours}

The most working hours are not tied to the hour, i.e. 6 attempts, while using working hours between 8-9 hours as much as 1 business and for working hours above 9 hours also as much as 3 attempts. The business day of Golla Kambu use erratic weekdays, which is as many as 8 attempts and 2 businesses that use weekdays for 7 days in every day.

Table 4. Working hours on Golla Kambu business in Lagi-Agi Village, Campalagian Subdistrict

\begin{tabular}{cccc}
\hline No & Working Hours & Number & Percentage \\
\hline 1 & $>9$ hours & 3 & $30 \%$ \\
2 & 8-9 hours & 1 & $10 \%$ \\
4 & No tied hours & 6 & $60 \%$ \\
\hline 5 & Total & 10 & $100 \%$
\end{tabular}

Source: Primary data processed (2017)

\subsection{Development Strategy of Golla Kambu Business}

Some empowerment strategy for Golla Kambu in Desa again-Agi district Campalagian, namely:

SO Strategy

1. Utilization of workforce from surrounding areas to increase production

2. More introducing that Lagi-Agi Village is a typical food center, including Golla Kambu

WO Strategy

1. Optimization of business management by increasing capital so that the goods are produced more leverage.

ST Strategy

1. Maintain without preservatives products to be able to compete with other products.

2. Increase the existing capital to meet the price of raw materials.

WT Strategy

1. Rely on cooperation with other merchants outside the region for a wider distribution process.

2. To create innovations in product packaging, to have a high appeal.

\section{Conclusion}

Based on the results and discussion, the research can be concluded that the human resource condition, technology, capital and marketing on Golla Kambu business in Lagi-Agi Village, Campalagian Subdistrict:

1. Human resources in Campalagian Subdistrict is quite available.

2. The technology used from the whole entrepreneur is a traditional tool furnace. In the business of Golla Kambu the use of traditional tools has been very suitable because the use of technology in the production process can affect the flavor.

3. Capital used by entrepreneurs is still relatively low.

4. The area of marketing products Golla Kambu is still very limited that is still in the market in the Campalagian area. 
The strategies that can be used to develop Golla Kambu's business are:

1. utilization of workforce from surrounding areas to increase production;

2. more introducing again that Lagi-Agi Village is a typical food center, including Golla Kambu;

3. optimization of business management by increasing capital so that the goods are produced more maximal;

4. maintain products of Tampa preservatives in order to be able to compete with other products;

5. increase the existing capital to meet the price of raw materials;

6. rely on cooperation with other merchants outside the region for a wider distribution process; and

7. to create innovations in product packaging, in order to have high attractiveness.

\section{References}

1. Anoraga P, Djoko S. Koperasi, kewirausahaan, dan usaha kecil. Jakarta: PT Rineka Cipta; 2002. 356 p.

2. Pangan jajanan yang sehat. Direktorat Perlindungan Konsumen, Depatemen Perdagangan RI Jakarta; 2006.

3. Polewali Mandar dalam angka 2010. Polewali: BPS Kabupaten Polewali Mandar; 2010.

4. Report of the Dinas Tenaga Kerja dan Transmigrasi Provinsi Sulawesi Barat; 2014.

5. Kotler P. Manajemen pemasaran. Jakarta: PT Macanan Jaya; 2009.

6. Tjiptono F, Gregious C, Adriana, D. Pemasaran strategik. Yogyakarta: Andi Offset; 2008. 746 p. 